\title{
Diversity of Rhizobium leguminosarum from Pea Fields in Washington State
}

\author{
Rita Abi-Ghanem, ${ }^{1}$ Jeffrey L. Smith, ${ }^{2}$ and George J. Vandemark ${ }^{3}$ \\ ${ }^{1}$ Department of Crop and Soil Sciences, Washington State University, Pullman, WA 99164-6420, USA \\ ${ }^{2}$ Land Management and Water Conservation Research Unit, USDA-ARS and Washington State University, Pullman, \\ WA 99164-6421, USA \\ ${ }^{3}$ Grain Legume Genetics Physiology Research, USDA-ARS and Washington State University, Pullman, WA 99164-6421, USA \\ Correspondence should be addressed to Rita Abi-Ghanem; rita_ag@wsu.edu
}

Received 19 December 2012; Accepted 13 January 2013

Academic Editors: G. Benckiser, J. A. Entry, H. K. Pant, and A. P. Schwab

Copyright (C) 2013 Rita Abi-Ghanem et al. This is an open access article distributed under the Creative Commons Attribution License, which permits unrestricted use, distribution, and reproduction in any medium, provided the original work is properly cited.

\begin{abstract}
Rhizobia-mediated biological nitrogen $(\mathrm{N})$ fixation in legumes contributes to yield potential in these crops and also provides residual fertilizer to subsequent cereals. Our objectives were to collect isolates of Rhizobium leguminosarum from several pea fields in Washington, examine genetic diversity among these isolates and several commercial isolates of R. leguminosarum, and compare genetically distinct isolates for their ability to fix $\mathrm{N}$ in a range of pea hosts. Seventy-nine isolates were collected from pea root from four noninoculated pea fields. Sequence-related amplified polymorphism (SRAP) markers generated by PCR were used to discriminate among isolates. Isolates fell into 17 clusters with robust bootstrap support values. Nearly half of the isolates fell into a single large cluster, but smaller clusters were also detected for isolates from all four field locations. The majority of commercial isolates fell into a distinct cluster. Four genetically distinct isolates were compared for their efficiency in fixing $\mathrm{N}$ in a greenhouse experiment. Host plant variety effects were significant for plant biomass due to $\mathrm{N}$ fixation and also for the quantity of $\mathrm{N}$ fixed per variety. Significant effects of $R$. leguminosarum isolates were observed for the quantity of $\mathrm{N}$ fixed per isolate, plant biomass, and the quantity of $\mathrm{N}$ per plant.
\end{abstract}

\section{Introduction}

Global demand for food will increase commensurately with a world population that may grow to reach 8.3 billion by 2025 [1]. Such increased demand will most likely occur in developing countries, many of which suffer from limited access to fertilizers and other exogenous farm inputs [1]. Furthermore, in the US, there are competing energy demands for limited supplies of natural gas required by the HaberBosch process in the nitrogen- $(\mathrm{N}-)$ fertilizer industry.

Rhizobia-mediated biological N fixation, which occurs on legume roots, can provide residual fertilizer to subsequent small grain crops. Specifically, rhizobiaceae are free-living diazotrophic saprophytes able to form nitrogen- (N-) fixed symbiotic associations with legumes by forming root nodules. Pea plants (Pisum sativum L.) are nodulated by Rhizobium leguminosarum bv. viciae [2]. The efficiency of biological
$\mathrm{N}$ fixation is also influenced by many environmental factors including soil conditions, such as acidity, temperature, mineral nutrients, salinity, alkalinity [1], high nitrogen and phosphorus levels [3], and soil type $[4,5]$. The influence of these environmental factors can be seen in the differences in the amount of $\mathrm{N}$ fixed in nodules of pea roots observed across different regions of pea production. For instance, the average $\mathrm{N}$ fixed by pea plants is $200 \mathrm{~kg} \mathrm{ha}^{-1}$ in Europe [6] and $83 \mathrm{~kg} \mathrm{ha}^{-1}$ in Australia, where peas are grown under rain-fed conditions [7].

Legume-rhizobial symbiosis is species-specific, but some recent studies have found that this symbiosis may even be cultivar-strain-specific. That is, different varieties within the same plant species may prefer different optimal rhizobial strains for maximum $\mathrm{N}$ fixation. In several legumes, including pea (Pisum sativum L.) [8] and chickpea (Cicer arietinum L.) [9], significant plant host, strain, and host $\mathrm{x}$ 
strain interaction effects have been observed on $\mathrm{N}$ fixation. Abi-Ghanem et al. [10] examined $\mathrm{N}$ fixation in growth chamber experiments using three yellow pea and two green pea cultivars, in which plants were inoculated separately with fifteen different $R$. leguminosarum bv. viciae commercial inoculants. Significant differences were observed among pea cultivars for the percentage of plant $\mathrm{N}$ supplied by bacterial $\mathrm{N}$ fixation and also for the number of root nodules formed per plant [10]. In the case of lentils, significant effects among different commercial inoculants were observed on the percentage of total plant $\mathrm{N}$ supplied by bacterial $\mathrm{N}$ fixation, whereas inoculant effects were not significant for peas [10].

The significant effects of commercial inoculants on $\mathrm{N}$ fixation in pea observed by Abi-Ghanem et al. [10] cannot conclusively be due to genetic differences among $R$. leguminosarum bv. viciae isolates that constitute the various commercial inoculants. This is because no definitive proof has provided that the commercial inoculants were composed of genetically distinct bacterial isolates. This information is critical in determining if differences among commercial inoculants in their ability to fix $\mathrm{N}$ in legume hosts are due to genetic differences among bacterial strains or due to another component or process of the product formulation. Information on genetic diversity among bacterial isolates will also assist in assessing relatedness between indigenous $R$. leguminosarum bv. viciae strains and strains present in commercial inoculant preparations. Presently, it is not clearly known how commercial inoculants compete with indigenous R. leguminosarum bv. viciae strains. Examples have reported on both the inability of commercial inoculants to compete with indigenous strains [11] and the successful competitive ability of commercial inoculants [12].

Applying genetic approaches to rhizobia analysis will better define plant-rhizobia interactions and processes involving nodulation and nitrogen fixation. Genetic diversity among rhizobial symbionts of diverse legume species has been observed based on restriction site polymorphism of $16 \mathrm{~S}$ rRNA genes and by PCR DNA fingerprinting with repetitive sequences [13]. Genetic polymorphisms have previously been used to improve bacterial taxonomy and characterize novel strains Mesorhizobium trianshanense with better $\mathrm{N}$ fixing efficiencies [14]. The primary objectives of this study were to collect $R$. leguminosarum isolates from peas in Washington State and examine genetic diversity among these isolates and commercial strains using both $16 \mathrm{~S}$ rDNA sequence analysis and sequence-related amplified polymorphisms (SRAP). Biological nitrogen fixation was also examined using different pea cultivars and a subset of genetically distinct isolates of $R$. leguminosarum bv. viciae.

\section{Materials and Methods}

2.1. Isolation of R. leguminosarum. Plant and soil samples were collected from noninoculated pea fields in Whitman County, Washington, USA (Spillman, Shawnee, Oakesdale, Colton, and Colfax). Cultivars were Aragorn for all fields except Colton, where Banner peas were instead planted. Samples were collected at $15-20 \mathrm{~cm}$ depth following an W pattern across the field. Equal amounts of soil were sampled at $15-20 \mathrm{~cm}$ depths from five different locations within a field and mixed together. Soil samples were then commercially analyzed to assess soil acidity, nitrate-N, ammonium-N, sulfate-S, phosphorus, potassium, boron, zinc, manganese, copper, and iron contents (Soiltest Farm Consultants, Inc. Moses Lake, WA, USA). Twenty plants were selected based on the presence of rhizobial nodulation. Pea roots were thoroughly washed, and nodules were sterilized with $0.5 \%$ sodium hypochlorite for $1 \mathrm{~min}$ and then passed quickly through a flame for surface disinfection. Nodules were cut and squeezed to extract liquid containing inoculum, which was applied to an inoculation loop. Inoculum was streaked on yeast extract mannitol agar (YEMA) (Bacto, Inc., Sparks, MD, USA) plates and incubated at $28^{\circ} \mathrm{C}$ for 3 days, after which a single colony was picked and restreaked on another YEMA plate. A single colony from this was then used to inoculate sterile tubes containing $3 \mathrm{~mL}$ of yeast extract mannitol broth (YEMB) (Bacto, Inc., Sparks, MD, USA) and agitated at $250 \mathrm{rpm}$ on an orbital shaker at $28^{\circ} \mathrm{C}$ for 5 days. An $800 \mu \mathrm{L}$ sample of each cultured strain was cryopreserved in $20 \%$ glycerol at $-80^{\circ} \mathrm{C}$. Commercial rhizobial strains used in this study were also stored at $-80^{\circ} \mathrm{C}$. The commercial strains of Rhizobium leguminosarum bv. viciae were obtained from cooperating companies. Novozymes Biologicals (Saskatchewan, Canada) provided eight strains (S007A-2, S008B-3, S012 A-3, S016B4, S019A-1, S030A-4, S068A-1, and S007A-5); Becker Underwood (Iowa, USA) supplied five strains (P2, 082, 212-9, 2135, ICAR 20), and EMD (Wisconsin, USA) provided three (EMD1, EMD2, and EMD3).

2.2. DNA Extraction and PCR. Genomic DNA was extracted from the cultured strains using the Fast DNA SPIN kit (MP Biomedicals Inc., OH, USA) according to the manufacturer's instructions. DNA was quantified with a fluorometer (TD700; Turner Designs, Inc., Sunnyvale, CA, USA) and diluted to $10 \mathrm{ng} / \mu \mathrm{L}$ for use in PCR. An $1340 \mathrm{bp}$ product corresponding to nearly the full length of the $16 \mathrm{~S}$ rRNA gene was amplified by PCR [15] using the forward primer fD1 $\left(5^{\prime}\right.$-AGAGTTTGATCCTGGCTCAG- $\left.3^{\prime}\right)$ and reverse primer rD1 ( $5^{\prime}$-AAGGAGGTGATCCAGCC- $\left.3^{\prime}\right)$. PCR reactions were performed using a Veriti thermal cycler (Applied Biosystems, Foster City, CA, USA) in $25 \mu \mathrm{L}$ reactions containing $100 \mathrm{ng}$ DNA; $200 \mu \mathrm{M}$ each dNTP; $1.5 \mathrm{mM} \mathrm{MgCl}_{2} ; 2.5$ units GoTaq Flexi DNA polymerase (Promega Corp., Madison, WI, USA); $5 \mu \mathrm{L} 5 \mathrm{X}$ GoTaq Flexi Buffer, and $0.2 \mu \mathrm{M}$ of both forward and reverse primers. Cycling conditions consisted of a single cycle of $95^{\circ} \mathrm{C}$ for $2 \mathrm{~min}$, followed by 30 cycles of $94^{\circ} \mathrm{C}$ for $40 \mathrm{~s}, 52^{\circ} \mathrm{C}$ for $40 \mathrm{~s}$, and $72^{\circ} \mathrm{C}$ for $1 \mathrm{~min}$, and a final extension cycle at $72^{\circ} \mathrm{C}$ for $7 \mathrm{~min}$. Amplicons were resolved on $1.5 \%$ agarose gels in TBE buffer (1X TBE, $90 \mathrm{mM}$ Tris $\mathrm{pH} 8.0$, $90 \mathrm{mM}$ boric acid, $2 \mathrm{mM}$ EDTA), stained with ethidium bromide and visualized with UV light. Amplicons were purified using a SureClean purification solution (Bioline Inc., MA, USA) as per the manufacturer's instructions, and the purified DNA samples were then commercially sequenced (Elim Biopharmaceuticals, Inc., CA., USA). Sequences were edited, and a consensus sequence for each amplicon was 
TABLE 1: Reverse and forward primers used for sequence-related amplified polymorphism (SRAP) analysis.

\begin{tabular}{|c|c|}
\hline Forward primers & Reverse primers \\
\hline ME2, 5'-TGAGTCCAAACCGGAGC-3' & EM1, 5' -GACTGCGTACGAATTAAT-3' \\
\hline F7, 5'-GTAGCACAAGCCGGAGC-3' & EM2, $5^{\prime}$-GACTGCGTACGAATTTGC-3' \\
\hline \multirow[t]{6}{*}{ F9, $5^{\prime}$-GTAGCACAAGCCGGACC- $3^{\prime}$} & EM3, 5'-GACTGCGTACGAATTGAC-3' \\
\hline & EM4, $5^{\prime}$-GACTGCGTACGAATTTGA-3' \\
\hline & EM5, $5^{\prime}$-GACTGCGTACGAATTAAC-3' \\
\hline & EM6, 5'-GACTGCGTACGAATTGCA-3' \\
\hline & R7, 5' -GACACCGTACGAATTTGC-3' \\
\hline & R10, 5' -GACACCGTACGAATTAAC-3' \\
\hline
\end{tabular}

derived using Geneious software version 5.0 [16]. Consensus sequences were compared with GenBank accessions by a BLAST search. Phylogenetic analyses by the neighbor-joining method and a consensus tree were generated using Molecular Evolutionary Genetics Analysis (MEGA) software version 5.0 [17].

2.3. SRAP Analysis. Ten forward and reverse primer pair combinations were selected based on preliminary tests to generate sequence-related amplified polymorphism (SRAP) [18] among rhizobia isolates. These primer pairs were designated as ME2/EM3, ME2/EM5, F7/EM1, F7/EM3, F7/EM4, F7/EM5, F9/EM2, F9/EM6, F9/R7, and F9/R10 (Table 1). All SRAP reactions were performed using a Veriti thermal cycler (Applied Biosystems, Foster City, CA, USA) in $25 \mu \mathrm{L}$ reactions containing $100 \mathrm{ng}$ DNA; $200 \mu \mathrm{M}$ each dNTP; $1.5 \mathrm{mM}$ $\mathrm{MgCl}_{2} ; 2.5$ units GoTaqFlexi DNA polymerase (Promega Corp., Madison, WI, USA); $5 \mu \mathrm{L} 5 \mathrm{X}$ GoTaqFlexi Buffer, and $37.5 \mathrm{ng}$ of both forward and reverse primers. The thermal cycling profile for all reactions consisted of a single cycle of $95^{\circ} \mathrm{C}$ for $2 \mathrm{~min}$ followed by 5 cycles of $94^{\circ} \mathrm{C}$ for $1 \mathrm{~min}, 35^{\circ} \mathrm{C}$ for $1 \mathrm{~min}, 72^{\circ} \mathrm{C}$ for $1 \mathrm{~min}, 35$ cycles of $94^{\circ} \mathrm{C}$ for $1 \mathrm{~min}, 50^{\circ} \mathrm{C}$ for $1 \mathrm{~min}, 72^{\circ} \mathrm{C}$ for $1 \mathrm{~min}$, and a final extension at $72^{\circ} \mathrm{C}$ for $7 \mathrm{~min}$. PCR products were resolved on $1.4 \%$ agarose gels in TBE buffer (1X TBE, $90 \mathrm{mM}$ Tris $\mathrm{pH} 8.0,90 \mathrm{mM}$ boric acid, and $2 \mathrm{mM}$ EDTA) and run at $125 \mathrm{~V}$ for $3.5 \mathrm{hr}$. Gels were stained for $30 \mathrm{~min}$ in ethidium bromide, and amplicons were visualized with UV light.

2.4. Data Analysis. Electrophoretic agarose gel images were scored visually for the presence or absence of polymorphic and monomorphic amplicons. All amplicons having molecular weights greater than $150 \mathrm{bp}$ were included in the analysis. Mean genetic distance between all pairwise combinations was calculated using GenAlEx software [19].

Cluster analysis was performed based on a previously described genetic distance method [20]. The unweighted pair group arithmetic average (UPGMA) method was used for analysis and a dendrogram was generated using PAUP software version 4.0 [21]. Bootstrap support for clusters was determined using 1000 permuted data sets [22].

2.5. N Fixation Study. Four strains isolated from four locations and with distinct genetic fingerprints were selected to assess $\mathrm{N}$ fixation. The selected isolates were designated as SP1; Oak1; Coll; and Sh2 and were collected from Spillman, Oakesdale, Colton, and Shawnee fields, respectively. The pea varieties selected for examination included three spring food grade green peas (Ariel, Aragorn, and Stirling) and two spring animal food grade yellow peas (Delta and Universal). Seeds were surface-disinfected with $0.5 \%$ sodium hypochlorite for three min and washed three times with sterile distilled deionized water. Seeds were germinated for five days on moist sterile filter paper at room temperature $\left(22-24^{\circ} \mathrm{C}\right)$. At the day of planting in a greenhouse, seeds were sown, one per pot, in cones $(6.4 \mathrm{~cm} \times 36 \mathrm{~cm})(\mathrm{SC10}$ container, Stuewe \& Sons, Inc.) containing a mix of sterile sand, perlite, and LECA clay (2:1:1 by volume). Colony density was determined based on spectrophotometry (BioRad, Hercules, CA, USA) using the optical density measured at $640 \mathrm{~nm}$. Each pot was inoculated with one of the selected R. leguminosarum strains using $1 \mathrm{~mL}$ of inocula containing $10^{6} \mathrm{cfu} \mathrm{mL}^{-1}$. Control plants were not inoculated with rhizobia. As previously described [23], pots were placed in a plastic tray filled with $\mathrm{N}$-free plant nutrient solution containing $1.0 \mathrm{mM} \mathrm{K}_{2} \mathrm{SO}_{4}, 0.5 \mathrm{mM} \mathrm{KH}_{2} \mathrm{PO}_{4}, 0.25 \mathrm{mM} \mathrm{K}_{2} \mathrm{HPO}_{4}, 0.5 \mathrm{mM}$ $\mathrm{MgSO}_{4} \cdot 7 \mathrm{H}_{2} \mathrm{O}, 2.0 \mathrm{mM} \mathrm{CaSO}_{4} \cdot 2 \mathrm{H}_{2} \mathrm{O}, 25 \mathrm{uM} \mathrm{KCl}, 13 \mathrm{uM}$ $\mathrm{H}_{3} \mathrm{BO}_{3}, 1.0 \mathrm{uM} \mathrm{MnSO} \cdot \mathrm{H}_{2} \mathrm{O}, 1.0 \mathrm{uM} \mathrm{ZnSO} \cdot \cdot 7 \mathrm{H}_{2} \mathrm{O}, 0.25 \mathrm{uM}$ $\mathrm{CuSO}_{4} \cdot 5 \mathrm{H}_{2} \mathrm{O}, 2.5 \mathrm{uM} \mathrm{CoCl} \cdot 6 \mathrm{H}_{2} \mathrm{O}, 20 \mathrm{uM} \mathrm{FeCl} 3 \cdot 6 \mathrm{H}_{2} \mathrm{O}$, and $0.25 \mathrm{uM} \mathrm{Na} \mathrm{MoO}_{4} \cdot 2 \mathrm{H}_{2} \mathrm{O}$. Pots were irrigated with $50 \mathrm{~mL}$ of sterile water on a daily basis for the first 2 weeks and then 3 times per week until harvesting occurred after 10 weeks, with the exception of the second set of the experiment, which was harvested after 8 weeks due to an infestation of mites in the greenhouse.

Upon harvesting, plant roots were washed, and the plants were dried at $60^{\circ} \mathrm{C}$ for 3 days and then weighed. Dried plants were passed through a Wiley mill to homogenize the sample and then powdered through a roller grinder. Total \% nitrogen $(\mathrm{N})$ and \% carbon (C) were measured using an elemental combustion system (Costech Instruments, USA) and were then multiplied by the plant total biomass to determine the quantity of $\mathrm{N}$ per plant. The quantity of $\mathrm{N}$ fixed was estimated by subtracting the quantity of $\mathrm{N}$ of the control plants from those treated. Biomass resulting from $\mathrm{N}$ fixation was calculated by subtracting the total biomass of control plants from the total biomass of those treated. 
TABLE 2: Results of soil analysis from fields where rhizobial isolates were collected.

\begin{tabular}{|c|c|c|c|c|c|c|c|c|c|c|}
\hline \multirow{2}{*}{ Location } & \multicolumn{10}{|c|}{ Soil factor } \\
\hline & $\mathrm{pH}$ & $\begin{array}{c}\text { Ammonium-N } \\
\left(\mathrm{mg} \cdot \mathrm{kg}^{-1}\right)\end{array}$ & $\begin{array}{l}\text { Nitrate-N } \\
\left(\mathrm{mg} \cdot \mathrm{kg}^{-1}\right)\end{array}$ & $\begin{array}{c}\text { Phosphorus } \\
\left(\mathrm{mg} \cdot \mathrm{kg}^{-1}\right)\end{array}$ & $\begin{array}{c}\text { Potassium } \\
\left(\mathrm{mg} \cdot \mathrm{kg}^{-1}\right)\end{array}$ & $\begin{array}{c}\text { Boron } \\
\left(\mathrm{mg} \mathrm{kg}^{-1}\right)\end{array}$ & $\begin{array}{c}\text { Zinc } \\
\left(\mathrm{mg} \mathrm{kg}^{-1}\right)\end{array}$ & $\begin{array}{c}\text { Manganese } \\
\left(\mathrm{mg} \cdot \mathrm{kg}^{-1}\right)\end{array}$ & $\begin{array}{c}\text { Copper } \\
\left(\mathrm{mg} \cdot \mathrm{kg}^{-1}\right)\end{array}$ & $\begin{array}{c}\text { Iron } \\
\left(\mathrm{mg} \cdot \mathrm{kg}^{-1}\right)\end{array}$ \\
\hline Colton & 5.2 & 2.3 & 14.1 & 43 & 537 & 0.24 & 0.8 & 24.7 & 2.9 & 140 \\
\hline Colfax & 5.9 & 1.5 & 6.9 & 17 & 169 & 0.24 & 0.3 & 6.9 & 2.6 & 60 \\
\hline Oakesdale & 5.6 & 2.6 & 6.4 & 16 & 124 & 0.13 & 0.3 & 8.9 & 3.1 & 67 \\
\hline Shawnee & 6.0 & 2.5 & 18.5 & 25 & 274 & 0.42 & 1 & 10.8 & 2.4 & 103 \\
\hline Spillman & 5.8 & 2.8 & 6.5 & 17 & 124 & 0.17 & 0.5 & 5.8 & 2.5 & 73 \\
\hline
\end{tabular}

2.6. Experimental Design and Statistical Analysis. SAS Proc Mixed procedure [24] was used for statistical analyses. The data were analyzed as a split plot analysis of variance in a completely randomized design. Rhizobia strain, pea variety, and their interactions were considered fixed effects with the three replicate flats considered random. Differences in measured biomass and the amount of $\mathrm{N}$ fixed for each experimental unit were calculated and tested for significance at $P \leq 0.05$ using Tukey's multiple comparison method.

\section{Results}

3.1. Strains Isolation and Identification. A total of 79 rhizobial strains were isolated from pea root nodules. Comparison of the 16S rRNA gene sequences with GenBank accessions via BLAST search confirmed that the bacteria isolated from pea nodules and commercial isolates were R. leguminosarum.

3.2. Phylogenetic Analysis Based on $16 S$ rRNA Gene. The genetic diversity of native and commercial strains of Rhizobium based on sequence analysis of the 16S rRNA gene was represented by a phylogenetic tree. The tree revealed two clades with bootstraps exceeding $60 \%$ which did not demonstrate inter- or intrafield diversity among rhizobial isolates. Isolates from Shawnee appear to be more genetically diverse than those from other Palouse fields since they were found in both clades.

3.3. Phylogenetic Analysis Based on SRAP. DNA of 79 native and 16 commercial rhizobial isolates was successfully amplified by the ten SRAP primer pairs, and a total of 102 markers were resolved. The number of markers produced by each primer set ranged from 8 to 14 with an average of 10 markers per primer pair. The most polymorphic markers were present in the $\leq 10 \%$ frequency class with an absence of monomorphisms (Figure 1). The distance-based SRAP marker cluster analysis successfully discriminated the examined rhizobial isolates. A dendrogram revealed 17 clusters with bootstraps exceeding $60 \%$ (Figure 2). Nearly half of the isolates fell into a single large cluster (no. 1), but smaller clusters were also detected for isolates from all four field locations. Colton isolates were grouped into 2 lineages (clusters 1 and 2). Spillman isolates were grouped into 4 lineages (clusters 1, 3,4 , and 5). Shawnee isolates were grouped into 5 lineages

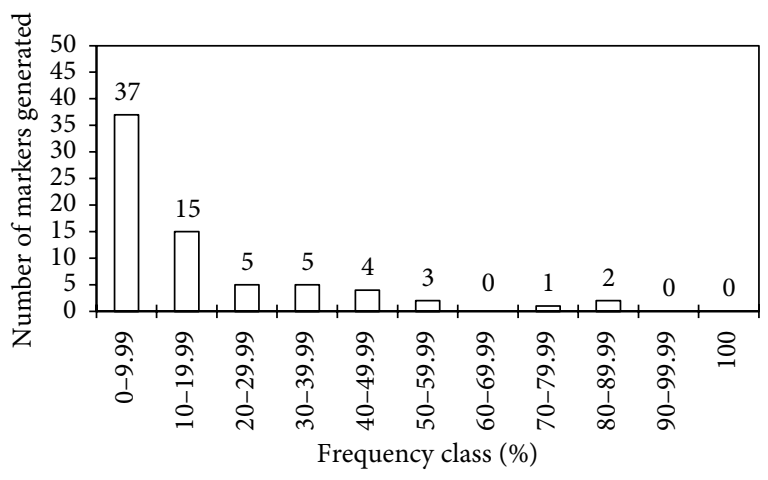

FIGURE 1: Number of sequence-related amplified polymorphism markers generated per frequency class, in percent, over 95 rhizobial DNA samples. Numbers above bars represent the actual numbers of markers.

(clusters 1, 9, 10, and 11). Oakesdale isolates were also grouped into 5 lineages (clusters $1,6,7$, and 8). Colfax isolates were grouped into 5 lineages (clusters, 12, 13, 14, and 15). None of the isolates from Colfax were in cluster 1 , the largest cluster identified in the analysis. Commercial strains were grouped into 3 lineages (clusters 1, 16, and 17). Shawnee field isolates had the highest mean genetic distance, while Spillman field isolates had the lowest mean genetic distance (Table 5).

3.4. Soil Test Analysis. Soil test results of the samples were obtained (Table 2). The $\mathrm{pH}$ values ranged from 5.2 in Colton to 6 in Shawnee. Ammonium-N was lowest in a Colfax field not previously cultivated for over a decade. Nitrate- $\mathrm{N}$ was highest in Colton and Shawnee fields. Phosphorus, potassium, manganese, copper, and iron contents were highest in the Colton field. Boron content was lowest in Oakesdale and Spillman field, and zinc content was highest in Shawnee field.

3.5. Nitrogen Study. Pea plant variety $(P=0.003)$ (Table 3 ) and rhizobial strain $(P=0.003)$ (Table 4$)$ significantly influenced the quantity of $\mathrm{N}$ fixed. Ariel plant variety contributed to higher quantity of $\mathrm{N}$ fixed than Delta (Table 3). The rhizobial strain (SP1) collected from Spillman field fixed greater quantities of $\mathrm{N}$ than Oak1 and Coll (Table 4). The interaction between plant variety and rhizobial strain did not significantly influence total biomass nor the quantity of $\mathrm{N}$ 


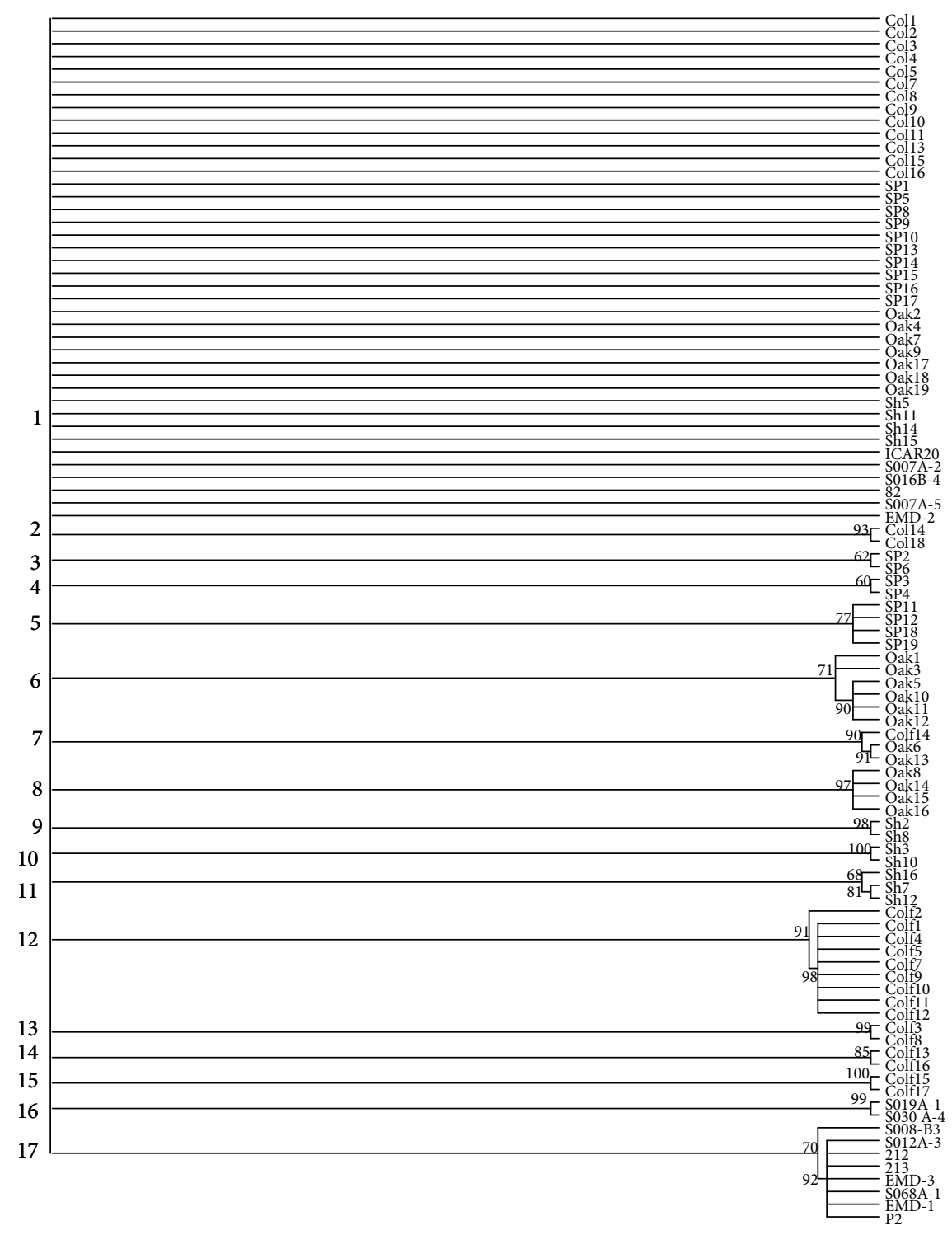

Figure 2: Dendrogram representing cluster analysis of 94 strains of $R$. leguminosarum based on 102 sequence-related amplified polymorphisms. Tree was constructed using UPGMA implemented in PAUP program 4 version [21]. Bootstraps values (1,000 replicates) are given at the branch nodes. Branches reproduced in less than $60 \%$ of bootstrap replicates were collapsed.

fixed. Pea plant variety $(P=0.036)$ (Table 3) and rhizobial strain $(P=0.009)$ (Table 4$)$ significantly influenced total biomass due to $\mathrm{N}$ fixation.

\section{Discussion}

Chromosomal variation was previously reported to be limited in R. leguminosarum [25]. However, other studies demonstrated heterogeneity amongst strains within natural populations [26, 27]. The degree of heterogeneity depended on the method used to assess variation and also on the targeted characteristics [28]. In these previous studies, methods based on the characterization of 16S-23S ribosomal DNA internal transcribed spacer PCR-restriction fragment length polymorphism and plasmid group-specific rep-C PCR amplification were used [3]. In other studies, rhizobial symbiont genetic diversity was determined by mapping restriction site polymorphism of the $16 \mathrm{~S}$ rRNA genes and by PCR DNA fingerprinting with repetitive sequences [13]. In this study, SRAP markers were used to examine genetic diversity among isolates of $R$. leguminosarum bv. viciae. The phylogenetic tree constructed by SRAP analysis demonstrated higher variability among rhizobial isolates than that from $16 \mathrm{~S}$ rRNA sequences. The distinct nature of Rhizobia from the Colfax field (Figure 2), which had not been cultivated for over a decade, may be attributed to selection pressures associated with the lack of cropping or agrichemical inputs at this location. In contrast to the Spillman field isolates having the lowest mean genetic distance, Shawnee and Colton fields 
TABLE 3: Mean values of total biomass, biomass due to nitrogen $(\mathrm{N})$ fixation, quantity $(\mathrm{Q})$ of $\mathrm{N}$ per plant, and quantity of $\mathrm{N}$ fixed by varieties ( $n=24$ for the treated plants, and $n=6$ for the control plants).

\begin{tabular}{|c|c|c|c|c|}
\hline Varieties & Total biomass ( $\mathrm{g} \mathrm{N})$ & Biomass due to $\mathrm{N}$ fixation ( $\mathrm{g} \mathrm{N}$ ) & $Q$ of N/plant (mg N) & $Q$ of $\mathrm{N}$ fixed $(\mathrm{mg} \mathrm{N})$ \\
\hline Delta & 1.22 & $0.26^{\mathrm{a}}$ & 23.78 & $4.96^{\mathrm{a}}$ \\
\hline Aragorn & 1.37 & $0.51^{\mathrm{ab}}$ & 25.57 & $8.17^{\mathrm{ab}}$ \\
\hline Stirling & 1.03 & $0.5^{\mathrm{ab}}$ & 18.73 & $8.7^{\mathrm{ab}}$ \\
\hline Universal & 1.41 & $0.45^{\mathrm{ab}}$ & 28.65 & $11.46^{\mathrm{ab}}$ \\
\hline Ariel & 1.6 & $0.93^{\mathrm{b}}$ & 31.09 & $19.07^{\mathrm{b}}$ \\
\hline$P$ value & 0.146 & 0.036 & 0.12 & 0.043 \\
\hline Delta-Ctr & 0.96 & $\mathrm{NA}^{*}$ & 18.7 & NA \\
\hline Aragorn-Ctr & 0.86 & NA & 17.39 & NA \\
\hline Stirling-Ctr & 0.53 & NA & 10.04 & NA \\
\hline Universal-Ctr & 0.96 & NA & 17.19 & NA \\
\hline Ariel-Ctr & 0.67 & NA & 12.02 & NA \\
\hline$P$ value & 0.267 & NA & 0.24 & NA \\
\hline
\end{tabular}

Letters that are the same within a column are not significantly different at $P \leq 0.05$.

${ }^{*}$ Statistical $P$ value is not applicable to this data.

TABLE 4: Mean values of biomass due to nitrogen (N) fixation, quantity $(Q)$ of $\mathrm{N}$ per plant, and quantity of $\mathrm{N}$ fixed by strains $(n=30)$.

\begin{tabular}{lccc}
\hline Strains & Biomass due to N fixation $(\mathrm{g} \mathrm{N})$ & Q of N/plant $(\mathrm{mg} \mathrm{N})$ & $Q$ of N fixed (mg N) \\
\hline Oak1 & $0.14^{\mathrm{a}}$ & $15.22^{\mathrm{a}}$ & $0.13^{\mathrm{a}}$ \\
Col1 & $0.21^{\mathrm{a}}$ & $17.13^{\mathrm{a}}$ & $2.03^{\mathrm{ab}}$ \\
Sh2 & $0.71^{\mathrm{ab}}$ & $28.92^{\mathrm{ab}}$ & $13.83^{\mathrm{bc}}$ \\
SP1 & $1.06^{\mathrm{b}}$ & $40.99^{\mathrm{b}}$ & $25.9^{\mathrm{c}}$ \\
$P$ value & 0.009 & 0.009 & 0.003 \\
\hline
\end{tabular}

Letters that are the same within a column are not significantly different at $P \leq 0.05$.

TABLE 5: Mean genetic distance of isolates within locations.

\begin{tabular}{lcc}
\hline Isolates & Isolates number & Genetic distance \\
\hline Col & 15 & 18.5 \\
SP & 18 & 10.3 \\
Oak & 19 & 16.3 \\
Sh & 11 & 29.5 \\
Colf & 16 & 17.1 \\
Commercial & 16 & 17.9 \\
\hline
\end{tabular}

isolates demonstrated higher mean genetic distance, which may reflect a higher diversity of $R$. leguminosarum isolates within the fields.

Previous studies have demonstrated a significant influence of plant variety on $\mathrm{N}$ fixation. Bello et al. [29] found $70 \%$ and $25 \%$ variability in $\mathrm{kg} \mathrm{N}$ fixed ha ${ }^{-1}$ among three soybean varieties at two sites. Hafeez et al. [30] found 9\%$48 \%$ PNF (proportion of plant $\mathrm{N}$ supplied by fixation) and $81 \%$ variability among Pakistani lentil varieties in a field trial. Abi-Ghanem et al. [10] found significant but relatively low $14.4 \%$ and $4.7 \%$ PNF variability among five USA lentil and pea varieties, respectively. In this study, host-plant variety significantly influenced the quantity of $\mathrm{N}$ fixed, suggesting the possibility of breeding for increased $\mathrm{N}$ fixation.

Averaged across all plant varieties, rhizobial strain significantly contributed to increased pea plant total biomass and quantity of $\mathrm{N}$ per plant. The rhizobial strain Sh2 in cluster 7 significantly had higher quantity of $\mathrm{N}$ fixed than Oak1. The rhizobial strain SP1 from Spillman field had higher quantity of $\mathrm{N}$ fixed than the Oak1 and Coll clustered in the same cluster 2 (Figure 2), suggesting that the clusters identified in this study are not representative of differences among isolates in their ability to fix N. The higher quantity of $\mathrm{N}$ fixed in the Spillman field strain may have been attributed to selection pressures encountered in this field, which had an optimal soil pH of 5.8 and low level of nitrate- $\mathrm{N}$ of $6.5 \mathrm{mg} \cdot \mathrm{kg}^{-1}$ [31].

The results presented in this study clearly demonstrate genetic differences among isolates of $R$. leguminosarum bv. viciae both within and between fields. Additional genetic analysis of the isolates examined in this study should allow for increased separation of isolates into distinct lineages. Continuing to examine genetic diversity among rhizobia isolates collected from peas grown in these same field locations will provide opportunities to examine changes in $R$. leguminosarum bv. viciae population dynamics associated with cultural practices.

\section{Conflict of Interests}

The authors do not have a direct financial relation with the commercial identities mentioned in this paper that might lead to a conflict of interests. 


\section{References}

[1] D. M. Sylvia, J. J. Fuhrmann, P. G. Hartel, and D. A. Zuberer, Principles and Applications of Soil Microbiology, Prentice Hall, Upper Saddle River, NJ, USA, 2nd edition, 2005.

[2] D. C. Jordan, "Rhizobiaceae," in Bergey's Manual of Systematic Bacteriology, N. R. Krieg, Ed., vol. 1, pp. 234-256, Williams \& Wilkins, London, UK, 1984.

[3] K. M. Palmer and J. P. W. Young, "Higher diversity of Rhizobium leguminosarum biovar viciae populations in arable soils than in grass soils," Applied and Environmental Microbiology, vol. 66, no. 6, pp. 2445-2450, 2000.

[4] P. M. Groffman, P. Eagan, W. M. Sullivan, and J. L. Lemunyon, "Grass species and soil type effects on microbial biomass and activity," Plant and Soil, vol. 183, no. 1, pp. 61-67, 1996.

[5] I. C. Mendes and P. J. Bottomley, "Distribution of a population of Rhizobium leguminosarum bv. trifolii among different size classes of soil aggregates," Applied and Environmental Microbiology, vol. 64, no. 3, pp. 970-975, 1998.

[6] E. S. Jensen, "The Role of Grain Legume $\mathrm{N}_{2}$ Fixation in the Nitrogen Cycling of Temperate Cropping Systems," RISO National Laboratory, Roskilde, Denamrk, 1997.

[7] M. J. Unkovich, J. S. Pate, and P. Sanford, "Nitrogen fixation by annual legumes in Australian Mediterranean agriculture," Australian Journal of Agriculture Research, vol. 48, no. 3, pp. 267-293, 1997.

[8] L. Skot, "Cultivar and rhizobium strain effects on the symbiotic performance of pea (Pisum sativum)," Plant Physiology, vol. 59, pp. 585-589, 1983.

[9] M. A. Sattar, M. A. Quader, and S. K. A. Danso, "Nodulation, $\mathrm{N}_{2}$ fixation and yield of chickpea as influenced by host cultivar and Bradyrhizobium strain differences," Soil Biology and Biochemistry, vol. 27, no. 4-5, pp. 725-727, 1995.

[10] R. Abi-Ghanem, L. Carpenter-Boggs, and J. L. Smith, "Cultivar effects on nitrogen fixation in peas and lentils," Biology and Fertility of Soils, vol. 47, no. 1, pp. 115-120, 2011.

[11] H. Moawad, S. M. S. Badr El-Din, and R. A. Abdel-Aziz, "Improvement of biological nitrogen fixation in Egyptian winter legumes through better management of Rhizobium," Plant and Soil, vol. 204, no. 1, pp. 95-106, 1998.

[12] N. H. Shah, F. Y. Hafeez, M. Arshad, and K. A. Malik, "Response of lentil to Rhizobium leguminosarum bv. viciae strains at different levels of nitrogen and phosphorus," Australian Journal of Experimental Agriculture, vol. 40, no. 1, pp. 93-98, 2000.

[13] G. Laguerre, P. Van Berkum, N. Amarger, and D. Prévost, "Genetic diversity of rhizobial symbionts isolated from legume species within the genera Astragalus, Oxytropis, and Onobrychis," Applied and Environmental Microbiology, vol. 63, no. 12, pp. 4748-4758, 1997.

[14] Z. Y. Tan, X. D. Xu, E. N. T. Wang, J. L. Gao, E. MartinezRomero, and W. X. Chen, "Phylogenetic and genetic relationships of Mesorhizobium tianshanense and related rhizobia," International Journal of Systematic Bacteriology, vol. 47, no. 3, pp. 874-879, 1997.

[15] W. G. Weisburg, S. M. Barns, D. A. Pelletier, and D. J. Lane, "16S ribosomal DNA amplification for phylogenetic study," Journal of Bacteriology, vol. 173, no. 2, pp. 697-703, 1991.

[16] A. J. Drummond, B. Ashton, M. Cheung et al., Geneious v 5.0, 2010.

[17] K. Tamura, D. Peterson, N. Peterson, G. Stecher, M. Nei, and S. Kumar, "MEGA5: molecular evolutionary genetics analysis using maximum likelihood, evolutionary distance, and maximum parsimony methods," Molecular Biology and Evolution, vol. 29, pp. 457-472, 2011.

[18] G. Li and C. F. Quiros, "Sequence-related amplified polymorphism (SRAP), a new marker system based on a simple PCR reaction: its application to mapping and gene tagging in Brassica," Theoretical and Applied Genetics, vol. 103, no. 2-3, pp. 455-461, 2001.

[19] R. Peakall and P. E. Smouse, "GENALEX 6: Genetic analysis in Excel. Population genetic software for teaching and research," Molecular Ecology Notes, vol. 6, no. 1, pp. 288-295, 2006.

[20] M. Nei and W. H. Li, "Mathematical model for studying genetic variation in terms of restriction endonucleases," Proceedings of the National Academy of Sciences of the United States of America, vol. 76, no. 10, pp. 5269-5273, 1979.

[21] D. L. Swofford, "PAUP: Phylogenetic Analysis Using Parsimony (and Other Methods)," Version 4. Sinauer Associates, Sunderland, Mass, USA, 2003.

[22] J. Felsenstein, "Confidence limits on phylogenies: an approach using the bootstrap," Evolution, vol. 39, pp. 783-791, 1985.

[23] T. R. McDermott and M. L. Kahn, "Cloning and mutagenesis of the Rhizobium meliloti isocitrate dehydrogenase gene," Journal of Bacteriology, vol. 174, no. 14, pp. 4790-4797, 1992.

[24] SAS Institute, "SAS Version 9.2 program and procedures guide," SAS Institute, Cary, NC, USA, 2008.

[25] J. P. W. Young, L. Demetriou, and R. G. Apte, "Rhizobium population genetics: enzyme polymorphism in Rhizobium leguminosarum from plants and soil in a pea crop," Applied and Environmental Microbiology, vol. 53, no. 2, pp. 397-402, 1987.

[26] E. S. P. Bromfield, S. B. Indu, and M. S. Wolynetz, "Influence of location, host cultivar and inoculation on the composition of naturalized populations of Rhizobium meliloti on Medicago sativa nodules," Applied and Environmental Microbiology, vol. 51, pp. 1077-1084, 1986.

[27] N. P. Thurman and E. S. P. Bromfield, "Effect of variation within and between Medicago and Melilotus species on the composition and dynamics of indigenous populations of Rhizobium meliloti," Soil Biology and Biochemistry, vol. 20, no. 1, pp. 31-38, 1988.

[28] K. D. Noel and W. J. Brill, "Diversity and dynamics of indigenous Rhizobium japonicum populations," Applied and Environmental Microbiology, vol. 40, pp. 931-938, 1980.

[29] A. B. Bello, W. A. Ceron-Dias, C. D. Nickell, E. O. Elsheriff, and L. C. Davis, "Influence of cultivar between-row spacing and plantpopulation of fixation of soybeans," Crop Science, vol. 20, pp. 751-775, 1980.

[30] F. Y. Hafeez, N. H. Shah, and K. A. Malik, "Field evaluation of lentil cultivars inoculated with Rhizobium leguminosarum bv. viciae strains for nitrogen fixation using nitrogen-15 isotope dilution," Biology and Fertility of Soils, vol. 31, no. 1, pp. 65-69, 2000.

[31] S. P. Harrison, D. G. Y. Jones, and J. P. W. Pung, "Rhizobium population genetics: genetic variation within and between populations from diverse locations," Journal of General Microbiology, vol. 135, pp. 1061-1069, 1989. 

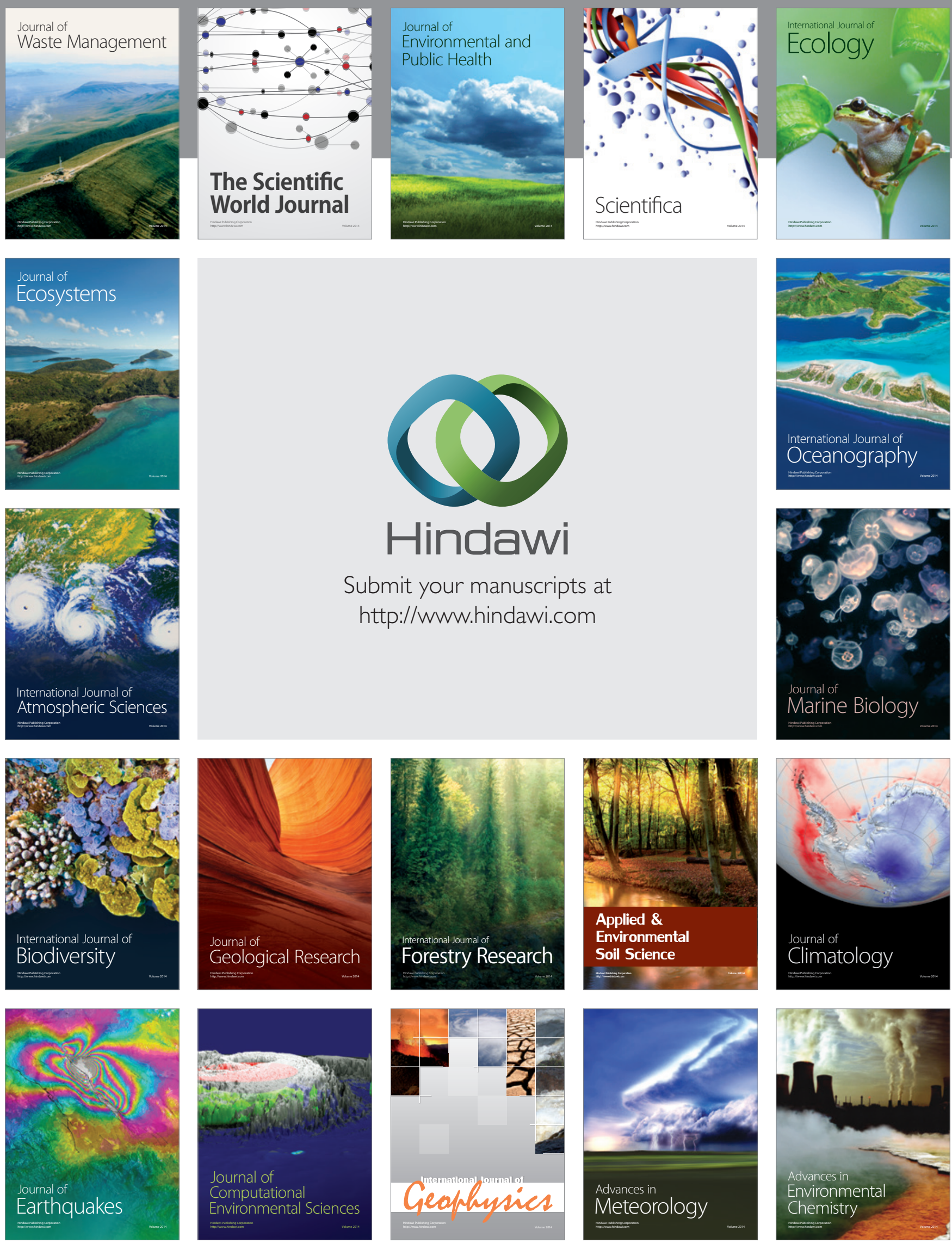